\title{
CORRELATION BETWEEN READING INTERESTS AND INDONESIAN LANGUAGE LEARNING OUTCOMES TO FIFTH GRADE STUDENTS OF PUBLIC ELEMENTARY SCHOOLS IN PEJAGOAN SUB-DISTRICT IN ACADEMIC YEAR OF 2019/2020
}

\author{
Ajiningrum Putri Ayu Dirgantari ${ }^{1}$, Joharman $^{2}$, Ngatman $^{3}$ \\ Sebelas Maret University \\ ajiningrum.putri@student.uns.ac.id
}

\section{Article History}

accepted 01/10/2020

approved 01/11/2020

published 01/12/2020

\begin{abstract}
The objectives of the research were to prove significant and positive correlation between reading interests and Indonesian language learning outcomes and to determine the contribution of reading interests on Indonesian language learning outcomes to fifth grade students in Pejagoan Sub-District in academic year of 2019/2020. The research was quantitative correlational study. The prerequisite test used the normality and linearity test. The data analysis included simple correlation test and adjusted $R$ square with significance level of $5 \%$. The results indicated that there was positive and significant relationship between reading interests and Indonesian language learning outcomes. The correlation was 0.539 and Adjusted $R$ square of reading interests on Indonesian language learning outcomes was $22.62 \%$. It concludes that there is significant and positive correlation between reading interests and Indonesian language learning outcomes to fifth grade students in Pejagoan sub-District in academic year of 2019/2020.
\end{abstract}

Keywords: reading interest, learning outcomes, Indonesian language

\begin{abstract}
Abstrak
Penelitian ini bertujuan untuk (1) membuktikan adanya korelasi positif yang signifikan antara minat membaca dengan hasil belajar bahasa Indonesia, (2) menghitung besarnya sumbangan minat membaca dengan hasil belajar bahasa indonesia siswa kelas $\mathrm{V}$ SDN se-Kecamatan Pejagoan tahun ajaran 2019/2020. Penelitian ini merupakan penelitian kuantitatif dengan metode korelasi. Uji prasyarat menggunakan uji normalitas dan linieritas. Analisis data dalam penelitian ini yaitu uji korelasi sederhana dan sumbangan efektif (SE). Kesimpulan dari penelitian ini adalah terdapat korelasi positif yang signifikan antara minat membaca dan hasil belajar bahasa indonesia dengan tingkat korelasi 0,539 dan sumbangan variabel minat membaca terhadap hasil belajar bahasa indonesia yaitu $22,62 \%$. Berdasarkan hasil penelitian tersebut dapat disimpulkan bahwa terdapat korelasi positif yang signifikan antara minat membaca dengan hasil belajar bahasa indonesia siswa kelas V SD Negeri se-Kecamatan Pejagoan tahun ajaran 2019/2020.
\end{abstract}

Kata kunci: minat membaca, hasil belajar, bahasa indonesia

\section{PENDAHULUAN}

Bahasa merupakan salah satu alat komunikasi yang digunakan oleh manusia di berbagai belahan dunia, menurut Dieu (2019: 358) bahasa tidak berasal dari kamus tetapi berasal dari generasi panjang umat manusia. Bahasa Indonesia merupakan bahasa resmi dan bahasa nasional yang digunakan masyarakat Indonesia untuk berkomunikasi. Bahasa Indonesia merupakan salah satu bidang studi yang dipelajari di seluruh jenjang pendidikan, dari tingkat sekolah dasar hingga perguruan tinggi. Pada 
jenjang sekolah dasar mata pelajaran bahasa indonesia menajadi salah satu mata pelajaran wajib yang hasus dikuasai oleh siswa.

Menurut Susanto (2016: 242) pembelajaran bahasa indonesia tidak dapat terlepas dari empat keterampilan, yaitu keterampilan menyimak, keterampilan berbicara, keterampilan, membaca, dan keterampilan menulis.

Salah satu keterampilan dalam pembelajaran bahasa indonesia yang harus dikuasai siswa adalah keterampilan membaca. Menurut Rahmawati (2018: 238) membaca merupakan hal yang sangat penting karena dengan membaca kita dapat memperoleh informasi. Kegiatan membaca dapat dilakukan siswa apabila siswa memiliki minat terhadap kegiatan membaca. Menurut Darmono (Kasiyun: 2015) minat membaca adalah kecenderungan jiwa yang mendorong seseorang berbuat sesuatu terhadap kegiatan membaca. Kegiatan membaca merupakan salah satu cara untuk memperoleh dan memperluas informasi secara langsung. Membaca merupakan kemampuan dan keterampilan untuk membuat penafsiran terhadap bahan yang dibaca sehingga seseorang dapat memahami makna dari sesuatu yang dibacanya. Dalam studi ilmu pengetahuan, hampir semua informasi yang diperoleh melalui kegiatan membaca. Pendapat dari Idris dan Izul (2015: 36) mengemukakan bahwa minat membaca adalah rasa ketertarikan yang lebih pada kegiatan penafsiran kata dalam bahasa tulis. Seorang siswa dapat dikatakan memiliki minat membaca apabila memenuhi ciri-ciri dan indikator minat membaca. Ciri-ciri siswa yang memiliki minat membaca menurut Slameto (2013: 180) adalah lebih suka membaca daripada hal lainnya, terlibat dalam kegiatan membaca, tertarik dalam kegiatan membaca, dan memberikan perhatian yang lebih besar pada kegiatan membaca. Menurut Arianingsih dan Setiana (2018: 251) indikator minat membaca adalah perasaan senang, tertarik, dan penuh perhatian pada kegiatan membaca. Pendapat ini sejalan dengan Safari (Maharani, Laksono, dan Sukartiningsih, 2017: 321-322) yang menyatakan empat aspek minat membaca yaitu perasaan senang, ketertarikan siswa, perhatian siswa, dan keterlibatan siswa. Kesadaran minat membaca siswa akan berpengaruh terhadap hasil belajar yang terdapat di sekolah dasar khususnya hasil belajar pada mata pelajaran bahasa indonesia. Karena mata pelajaran bahasa indonesia merupakan bidang studi yang mempelajari tentang keterampilan menyimak, berbicara, membaca, dan menulis.

Susanto (2016: 5) menegaskan bahwa hasil belajar sebagai perubahanperubahan yang terjadi pada diri siswa, baik yang menyangkut aspek kognitif, afektif, dan psikomotor sebagai hasil dari kegiatan belajar. Menurut sobur (2016: 212-218) terdapat dua faktor yang mempengaruhi hasil belajar siswa yaitu faktor endogen (faktor internal) dan faktor eksogen (faktor ekternal). Faktor endogen (faktor internal) meliputi kesehatan, perhatian dan minat, bakat, motivasi, dan kepribadian. Sedangkan faktor eksogen (faktor eksternal) meliputi pola asuh orang tua, lingkungan sekolah, lingkungan rumah, dan lainnya. Salah satu faktor endogen (faktor internal) yang memiliki pengaruh besar dalam hasil belajar adalah minat.

Berdasarkan uraian di atas, penting kiranya dilakukan penelitian untuk mengetahui ada tidaknya hubungan antara minat membaca dengan hasil belajar bahasa indonesia yang dimiliki siswa kelas V SD di Kecamatan Pejagoan melalui penelitian kuantitatif dengan judul "Hubungan Minat Membaca dengan Hasil Belajar Bahasa Indonesia Siswa Kelas V SDN se-Kecamatan Pejagoan Tahun Ajaran 2019/2020"

Tujuan penelitian ini adalah: (1) membuktikan ada tidaknya hubungan antara minat membaca dengan hasil belajar bahasa indonesia siswa kelas V SDN seKecamatan Pejagoan tahun ajaran 2019/2020; (2) menghitung besarnya sumbangan minat membaca terhadap hasil belajar bahasa indonesia siswa kelas V SDN seKecamatan Pejagoan tahun ajaran 2019/2020. 


\section{METODE}

Penelitian ini merupakan penelitian kuantitatif dengan metode korelasi. Populasi penelitian ini adalah seluruh siswa kelas V di 28 SDN se-Kecamatan Pejagoan tahun ajaran 2019/2020 yang berjumlah 759 siswa. Sample pada penelitian ini berjumlah 262 siswa kelas V di sepuluh SDN se-Kecamatan Pejagoan yang dipilih secara acak dengan teknik cluster random sampling. Pengambilan sampel dengan teknik cluster random sampling adalah pengambilan sampel terhadap kelompok (sekolah), bukan terhadap subjek secara individu. Sekolah yang digunakan pada penelitian ini yaitu SDN 1 Kuwayuhan, SDN 1 Logede, SDN 2 Karangpoh, SDN 2 Kedawung, SDN 2 Logede, SDN 2 Pejagoan, SDN 3 Kewayuhan, SDN 4 Kedawung, SDN 4 Pejagoan dan SDN Watulawang.

Teknik pengumpulan data pada penelitian ini menggunakan tes dan angket. Teknik tes digunakan untuk mengumpulkan data hasil belajar bahasa indonesia dan teknik angket digunakan untuk mengumpulkan data minat membaca. Uji prasyarat analisis data yang digunakan yaitu uji normalitas dan uji linieritas. Analisis data yang digunakan yaitu uji korelasi sederhana dan sumbangan efektif (SE) dengan taraf signifikansi $5 \%$.

\section{HASIL DAN PEMBAHASAN}

Penelitian ini dilakukan dengan memberikan angket minat membaca dan tes hasil belajar bahasa indonesia di sepuluh SDN di Kecamatan Pejagoan. Angket ini berisi pertanyaan-pertanyaan yang memuat indikator minat membaca sehingga dapat mengukur tinggi rendahnya minat membaca siswa. Tes berisi tentang soal-soal bahasa indonesia yang memuat indikator materi bahasa indonesia kelas $\mathrm{V}$ semester satu sehingga dapat mengukur tinggi rendahnya hasil belajar bahasa indonesia siswa. Prasyarat data terpenuhi yaitu data berasal dari populasi berdistribusi normal dan terdapat hubungan linier antara minat membaca dan hasil belajar bahasa indonesia siswa. Data hasil penelitian berasal dari data berdistribusi normal yang ditunjukkan dengan nilai signifikansi minat membaca 0,200 dan nilai signifikansi hasil belajar bahasa indonesia 0,200 . Kedua nilai signifikansi data menunjukkan nilai $>0,05$ sehingga data tersebut berasal dari populasi berdistribusi normal. Data dikatakan terdapat hubungan linier antara variabel $X$ dan $Y$ jika $p$ value Deviation from Linierity $>0,05$. Nilai $p$ value Deviation from Linierity yaitu $0,119>0,05$ sehingga terdapat hubungan linier antara minat membaca dengan hasil belajar bahasa indonesia siswa.

Korelasi antara minat membaca dan hasil belajar bahasa indonesia diuji menggunakan uji korelasi pearson product moment. Uji korelasi menggunakan bantuan aplikasi SPSS versi 25.

Hipotesis yang digunakan adalah $\mathrm{H}_{0}=$ tidak ada hubungan minat membaca dengan hasil belajar bahasa indonesia dan $\mathrm{H}_{1}=$ terdapat hubungan antara minat membaca dengan hasil belajar bahasa indonesia.

Tabel 1 Hasil Analisis Korelasi Minat Membaca dengan Hasil Belajar Bahasa Indonesia Correlations

\begin{tabular}{llr|r} 
& & $\begin{array}{c}\text { minat } \\
\text { membaca }\end{array}$ & $\begin{array}{r}\text { hasil belajar bahasa } \\
\text { indonesia }\end{array}$ \\
\hline minat membaca & Pearson Correlation & 1 &, $539^{* *}$ \\
\cline { 2 - 4 } & Sig. (1-tailed) & 262 &, 000 \\
\cline { 2 - 4 } & $\mathrm{N}$ &, $539^{* *}$ & 262 \\
\hline $\begin{array}{l}\text { hasil belajar } \\
\text { bahasa }\end{array}$ & Pearson Correlation &, 000 & 1 \\
\cline { 2 - 4 } & Sig. (1-tailed) & &
\end{tabular}




\begin{tabular}{l|r|r}
\hline indonesia $N$ & $\mathrm{~N}$ & 262 \\
\hline$* *$ Correlation is significant at the 0.01 level (1-tailed)
\end{tabular}

Berdasarkan analisis data menggunakan uji korelasi pearson product moment, diketahui bahwa terdapat hubungan positif yang signifikan antara minat membaca dengan hasil belajar bahasa indonesia siswa kelas $\mathrm{V}$ dengan koefisien korelasi sebesar 0,539 dan Sig.(1-taled) yaitu 0,000 ( $p$ value $<0,05$ ). Nilai 0,05 adalah taraf signifikansi yang digunakan pada penelitian ini. Sesuai dengan hasil uji korelasi tersebut, maka hipotesis yang menyatakan bahwa terdapat hubungan yang positif dan signifikan antara minat membaca dan hasil belajar bahasa indonesia siswa kelas $\mathrm{V}$ SDN se-Kecamatan Pejagoan tahun ajaran 2019/2020 dapat diterima. Hasil analisis koefisiensi korelasi antara variabel minat membaca dan variabel hasil belajar bahasa indonesia yaitu 0,539. Berdasarkan pendapat Sugiyono (2017:184) mengenai pedoman interprestasi terhadap koefisien korelasi menyatakan bahwa koefisien korelasi pada penelitian ini berada pada tingkat hubungan sedang.

Sesuai hasil perhitungan sumbangan minat membaca terhadap hasil belajar bahasa indonesia sebesar $22,62 \%$ dan $72,38 \%$ dipengaruhi oleh faktor lain. Hal ini sejalan dengan pendapat Solikhah (2016: 82) yang menyatakan bahwa minat membaca bukan satu-satunya faktor yang dapat mempengaruhi hasil belajar bahasa indonesia siswa, tetapi terdapat faktor-faktor lain yang dapat mempengaruhi tinggi rendahnya hasil belajar bahasa indonesia siswa.

Berdasarkan penelitian dan perhitungan yang telah dilakukan, dapat diketahui bahwa minat membaca memiliki hubungan yang positif dengan hasil belajar bahasa indonesia. Oleh karena itu, dapat dikatakan bahwa semakin tinggi minat membaca siswa maka akan semakin tinggi pula hasil belajar bahasa indonesia siswa. Begitu juga sebaliknya, semakin rendah minat membaca siswa, maka semakin rendah pula hasil belajar bahasa indonesia siswa.

Hasil penelitian ini sesuai dengan hasil penelitian yang dilakukan oleh Solikhah (2016: 80) yang menyatakan bahwa terdapat hubungan yang positif dan signifikan anatara minat membaca dengan hasil belajar bahasa indonesia dengan nilai pearson correlation sebesar 0,509. Pada penelitian Solikhah hasil belajr siswa dapat dipengaruhi oleh dua faktor, yaitu faktor internal dan faktor eksternal. Perbedaan penelitian yang dilakukan oleh Solikhah dengan penelitian ini terdapat pada subjek penelitian yang digunakan. Pada penelitian yang dilakukan oleh Solikhah dilakukan pada satu gugus sedangkan penelitian ini dilakukan di satu kecamatan. Penelitian lain yang dilakukan oleh Deviana, Syamsiati, dan Sabri (2017: 15) juga menunjukkan adanya hubungan positif antara minat membaca dengan hasil belajar bahasa indonesia. Perbedaan penelitian yang dilakukan oleh Deviana, Syamsiati, dan Sabri dengan penelitian ini terdapat pada kelas subjek penelitian. penelitian yang dilakukan oleh Deviana, Syamsiati, dan Sabri dilakukan pada kelas III SD sedangkan penelitian ini dilakukan pada kelas V SD.

Hasil perhitungan sumbangan efektif pada variabel minat membaca dan variabel hasil belajar bahasa indonesia didapatkan hasil sebesar $22,62 \%$, artinya minat membaca yang dimiliki siswa dapat berperan dalam meningkatkan hasil belajar bahasa indonesia sebesar $22,62 \%$ dan sisanya sebesar $72,38 \%$ dipengaruhi oleh faktor lain seperti kesehatan, motivasi, kemandirian, sarana, dan prasarana.

\section{SIMPULAN}

Berdasarkan hasil penelitian dan pembahasan yang telah diuraikan, maka dapat disimpulkan bahwa: (1) Minat membaca berkorelasi positif dan signifikan dengan hasil belajar Bahasa Indonesia siswa kelas V SD Negeri se-Kecamatan Pejagoan dengan tingkat korelasi sedang yaitu 0,539 ; (2) besar sumbangan efektif variabel minat membaca terhadap hasil belajar bahasa indonesia yaitu $22,62 \%$. 
Berdasarkan simpulan yang telah dipaparkan, peneliti memberikan beberapa saran: (1) bagi guru, selalu memotivasi siswa untuk meningkatkan minat membaca dengan memberikan teks bacaan yang menarik, membiasakan siswa untuk membaca sebelum pembelajaran, membiasakan siswa untuk berkunjung ke perpustakaan, dan membiasakan siswa untuk membaca buku minimal satu buku dalam satu minggu; (2) bagi sekolah, sebaiknya melengkapi referensi buku bacaan di perpustakaan; (3) bagi peneliti selanjutnya dapat melakukan penelitian terkait dengan faktor lainnya yang dapat mempengaruhi hasil belajar bahasa indonesia dan penelitian ini dapat menjadi acuan dalam penelitian korelasi serta diharapkan mencari referensi lainnya agar hasil penelitiannya akan jauh lebih baik.

\section{DAFTAR PUSTAKA}

Arianingsih, A. \& Setiana, S, M. (2018). Minat Belajar Mahasiswa terhadap Pembelajaran Chookai. Journal of Japanese Language Education \& Linguistics, 2 (2), 249-257.

Deviana, E., Syamsiati., \& Sabri, T. (2017). Korelasi Minat Baca dengan Hasil Belajar pada Pembelajaran Bahasa Indonesia Siswa Kelas III SD. Jurnal Pendidikan dan Pembelajaran, 6 (2), 1-16.

Dieu, T, T, T. (2019). Comparison Among Some View Points Upon Second Language Acquisition Theory. International Journal of Language and Linguistics, 7(6), 358-363

Idris, M, H. \& Izul, R. (2015). Menumbuhkan Minat Membaca pada Anak Usia Dini. Jakarta: Luxima

Kasiyun, S. (2015). Upaya Meningkatkan Minat Baca Sebagai Sarana Untuk Mencerdaskan Bangsa. Jurnal Pena Indonesia, 1 (2), 79-95.

Maharani, O, D., Laksono, K., \& Sukartiningsih, W. (2017). Minat Baca Anak-Anak di Kampoeng Baca Kabupaten Jember. Jurnal Review Pendidikan Dasar: Jurnal Kajian Pendidikan dan Hasil Penelitian, 3 (1), 320-328.

Rahmawati, E, Y. (2018). Analysis of Students' English Reading Comprehension through KWL (Know-Want-Learn) Learning Strategies. International Journal of Language Teaching and Education, 2 (3), 238-247.

Slameto. (2013). Belajar dan Faktor-Faktor yang Mempengaruhinya. Jakarta: Rineka Cipta.

Sobur, A. (2016). Psikologi Umum. Bandung: Pustaka Setia.

Solikhah, I, A. (2016). Hubungan Minat Baca dengan Hasil Belajar Bahasa Indonesia Siswa Kelas V SDN Gugus Dipayuda Kecamatan Banjarnegara Kabupaten Banjarnegara. Semarang: Universitas Negeri Semarang.

Sugiyono. (2017). Metode Penelitian Kuantitatif, Kualitatif, dan R\&D. Bandung: Alfabeta.

Susanto, A. (2016). Teori Belajar dan Pembelajaran di Sekolah Dasar. Jakarta: Prenadamedia Group. 